\title{
Caracteres psicológicos míticos insertos en la narrativa breve de Julio Cortázar
}

\author{
Alejandro Cantarero de Salazar \\ Universidad Complutense de Madrid \\ acsalazar@ucm.es
}

A Ángeles Nafría López, maestra y sabia $\mu \tilde{\omega} \lambda v$ enviada por Hermes...

Recibido: 6-09-2013

Aceptado: 11-12-2013

\section{RESUMEN}

El presente trabajo parte de la revisión de la primera creación mitológica de Julio Cortázar: Los reyes. Posteriormente se pasa a analizar las características literarias, a partir del análisis comparativo de «Circe», «Ménades» y sus fuentes clásicas, de la interpretación mitológica de Cortázar a través del modelo psicológico de Jung.

Palabras clave: Mitología, Minotauro, Circe, Ménades, literatura griega, Homero, Odisea, Bacantes de Eurípides, literatura hispanoamericana, Julio Cortázar, psicología.

\begin{abstract}
The present work begins by revising of the first mythological creation of Julio Cortázar: Los reyes. Afterwards we go on with the analysis of the literary characteristics, by a comparative analysis of "Circe", "Ménades" and their classical sources, of the mythological interpretation by the Jung`s psychological model.
\end{abstract}

Keywords: Mythology, Minotaur, Circe, Maenads, greek literature, Homer, Odyssey, Bacchae of Euripides, Spanish American literature, Julio Cortázar, psychology.

SUMARIO: 1 . Introducción. 2. El acercamiento de Julio Cortázar a las fuentes mitológicas clásicas: una primera apuesta por la relectura del mito de «Teseo y el Minotauro». 3. Casos concretos de recreación de temáticas clásicas en sus cuentos. 3.1. «Circe» de Bestiario: una mirada hacia la Circe homérica. 3.2. «Ménades» de Final de Juego: un nuevo grito de «evohé». 4. Conclusiones.

\section{INTRODUCCIÓN}

La mitología clásica no ha quedado dormida en la contemporaneidad, sirviendo de inspiración a muchos de los grandes artistas de nuestra época. Esta recepción de la mi- 
tología se ha visto vinculada, en muchas ocasiones, a una determinada interpretación del mito. De entre ellas destacamos: el historicismo (R. Graves), el estructuralismo (Propp y Levi-Strauss) y la vía psicologista. Esta última corriente se subdivide en dos vías encabezadas por Freud, la primera, y por Jung, la segunda. Julio Cortázar lee la materia clásica en sus fuentes más antiguas, entre las que podemos destacar a Homero y a Hesíodo. Sin embargo, esta lectura está profundamente orientada por el estudio de la interpretación del mito de Jung, como él mismo sugiere.

\section{EL ACERCAMIENTO DE JULIO CORTÁZAR A LAS FUENTES MITOLÓGICAS CLÁSICAS: UNA PRIMERA APUESTA POR LA RELECTURA DEL MITO DE «TESEO Y EL MINOTAURO»}

La idea del libro me nació en un colectivo [...] En uno de esos viajes en los que te aburres, de golpe sentí toda la presencia de algo que resultó ser mitología griega, lo cual creo que da la razón a Jung y a su teoría de los arquetipos, en el sentido de que todo está en nosotros y hay una especie de memoria de los antepasados, y que por ahí un archibisabuelo tuyo, que vivió en Creta cuatro mil años a.C., a través de los genes y de los cromosomas te manda algo que corresponde a su tiempo y no al tuyo. Tú, sin darte cuenta, escribes un cuento o una novela y en realidad estás transmitiendo un mensaje muy antiguo y muy arcaico... ${ }^{1}$

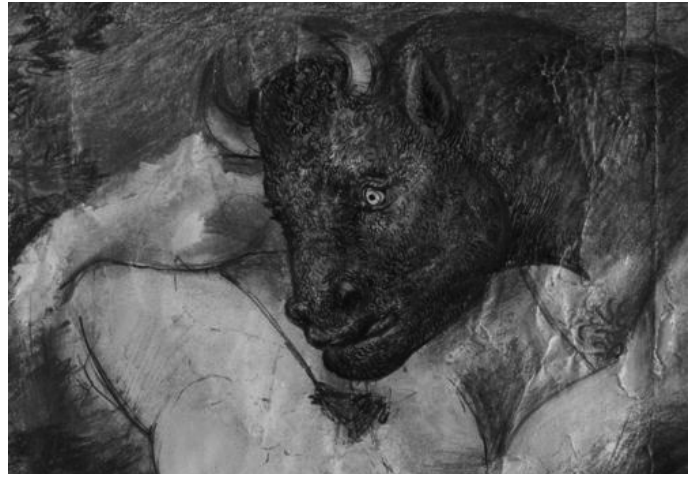

Fig 1. Detalle de Dora y el minotauro, 1936.

P. Picasso. París, Museo Picasso.

Carboncillo y tinta sobre papel.

Así se refería Julio Cortázar, en una entrevista concedida al programa $A$ Fondo, a una de sus primeras obras: Los reyes (1949). Carlos Dimeo Álvarez repara en el carácter híbrido de la composición, que si bien no puede considerarse dentro del género cuentístico que nos ocupa, sí que presenta cierto carácter narratológico, que se desarrollará en sus posteriores relatos ${ }^{2}$.

Por tanto, parece conveniente bosquejar brevemente la lectura que Cortázar nos propuso de este ya vetusto mito que aparecía, en una de sus primeras manifestaciones, en los Cretenses de Eurípides (430 a.C.) ${ }^{3}$, una tragedia conservada fragmentariamente. También aparece recogido en el Himno a Delos de Calímaco (v. 319 y ss.) y relatado por com-

${ }^{1}$ Entrevista de $A$ Fondo de Joaquín Soler Serrano a Julio Cortázar (1977), consultado en línea: http://www.youtube.com/watch?v=gmj2KvRVW1E .

${ }^{2}$ «Ambos elementos en el mito (Narración/Teatro) surgen como una poderosa metáfora de aparición (Texto/ representación). Un mito es una representación y al mismo tiempo una narración de algo, en principio por su particular y específico carácter fictivo, surgiendo de una pequeña, pequeñísima substancia real» Dimeo Álvarez (2012: 163-172).

${ }^{3}$ López Férez (2008: 352-395). 
pleto en la Biblioteca Mitológica de Apolodoro (III 1,4;15,8). Además lo encontramos en muchas obras latinas ${ }^{4}$. Parece verosímil que Cortázar empleara la Biblioteca de Apolodoro, por ser una de las obras que comprende el mito en mayor extensión, pues Ovidio en sus Metamorfosis es sumamente breve en el relato de esta historia ${ }^{5}$.

El mito, en su versión más extendida, narra cómo Minos, habiéndole concedido Posidón un toro blanco para ser sacrificado, prefiere añadirlo a sus ganados y ofrecer otro de menor majestuosidad como inmolación. El dios, enfurecido, le castiga haciendo que su esposa Pasífae quede enamorada de este toro blanco, del que se había apropiado injustamente. Así, Pasífae se introduce en una vaca de madera construida por Dédalo y yace con el toro, concibiendo a Asterio, llamado Minotauro: ser monstruoso con cabeza de toro y cuerpo humano. Para ocultar su vergüenza Minos encierra al Minotauro en el laberinto, diseñado también por Dédalo. Cada año, o cada nueve según Metamorfosis, se le entregaban como alimento siete muchachos y siete vírgenes atenienses, en pago por la muerte de Androgeo, hijo de Minos. Teseo, hijo del rey Egeo de Atenas, llega para acabar con el cruento convite que se le ofrecía a la bestia. Finalmente, con la ayuda de Ariadna (hija de Minos y Pasífae), que le proporciona un ovillo de hilo dorado para encontrar el camino de vuelta desde las sinuosidades del laberinto, Teseo es capaz de matar al Minotauro y retornar vivo.

Los reyes supone una primera irrupción en el mito, una primera apuesta por la interpretación o relectura, sin limitarse a la reescritura. En esta obra Cortázar adopta un lenguaje suntuoso, onírico, que parece «cantar y bailar», como él mismo afirmó en la entrevista referida supra, a uno de los mitos griegos; pero con una óptica desconocida. Según señala Gabriel Vaccaro, el mito presenta una perspectiva tradicional en cuanto al tiempo y al espacio en el que se desarrollan la historia, los personajes y el argumento. Sin embargo, es la inversión de las psicologías míticas, la que supone un punto de inflexión ${ }^{6}$. En este caso, como en muchos otros, Cortázar habla de exclusión ${ }^{7}$, para él el Minotauro no va a representar una oposición sanguinaria al orden civilizador establecido (Palacio de Cnosos); sino más bien una «oposición poética». Es decir, el Minotauro no devora a nadie, como se comprueba al final de su poema; sino que danza y juega con las supuestas víctimas ofrecidas. El Minotauro es aquí el perseguido, el poeta al que nadie entiende y al que el rey se dispone a matar, ayudado por Teseo. Este héroe es para Cortázar el «fascista» que mata a un ser al que no entiende, porque está fuera de su orden, fuera del orden onírico del laberinto ${ }^{8}$. Teseo se enfrenta a la palabra, acaba con ella, la mata sin piedad:

${ }^{4}$ Véase. VERG., A. 6, 26 y ss. ; CATUL. 64; OV., Ep.10; y OV., Met. 8, 153 y ss.

${ }^{5}$ «Ovidio es conscientemente breve, pues el tema del amor de Ariadna a Teseo, su ayuda, su salida de Creta y su ulterior abandono en la isla de Naxos, aquí llamada con su nombre mítico, había sido tratado por Catulo en el poema 64 y por él mismo en Heroidas X.» Álvarez \& Iglesias (2007: 473).

${ }^{6}$ Gabriel Vaccaro (2007). También se establece un análisis mitológico de Los reyes en Vicente Sánchez (2009: 966-968).

${ }^{7}$ Véase «Ómnibus», Cortázar (2003: 51-67) y también el relato de «Circe», que posteriormente analizaré en detalle.

${ }^{8}$ No hay que olvidar el simbolismo del laberinto en la obra de Borges. Para un estudio de la influencia clásica de este elemento en la obra de Borges véase: Huici (1998:121-259). 
Teseo: ¡Calla! ¡Muere al menos callando! ¡Estoy harto de palabras, perras sedientas! ¡Los héroes odian las palabras! ${ }^{9}$

Esta vuelta de óptica del conocido mito causó un gran revuelo en la crítica, pues se ponía en tela de juicio el papel del héroe. No podemos obviar que el mito del Minotauro fue recreado bajo esta misma perspectiva por Borges en su cuento «La casa de Asterión» ${ }^{10}$, incluido en el Áleph y publicado en 1949, mismo año en el que Cortázar publica Los reyes. En este breve relato de Borges la técnica que sirve para caracterizar al personaje es precisamente un cambio de perspectiva: el Minotauro narra su historia. Sin embargo, este hecho se ve reforzado por una estructura de rompecabezas que funciona, según señala Donald Leslie Shaw ${ }^{11}$, como una postergación sistemática que atrapa al lector, que no conoce hasta la última línea que es el propio monstruo el que narra la historia ${ }^{12}$.

Todas estas reflexiones podrían parecer fuera de lugar y alejadas de nuestro propósito. Sin embargo, constituyen el punto de partida de este análisis. En primer lugar hay que detenerse en el nuevo alcance que tiene el mito en este primer caso para Cortázar, que relega a un segundo plano el papel del héroe, del que ya veníamos reflexionando desde la antigüedad, para hablarnos del antihéroe, o de alguien aún más cercano a la cotidianidad que Cortázar busca siempre: el excluido. Esta primera observación nos conduce a una conclusión: Cortázar hace una interpretación psicológica de un perfil mitológico, y, en este caso, uno que parecía encerrado en un bestiario del que nada humano podía surgir. Es decir, el autor no se limitará a relatar el mito, a narrarlo con otras palabras; sino que decidirá cambiar de voz. Ahora es el turno del Minotauro, que va a desmentir todo lo que la tradición mitológica le ha asignado: él no ha matado a nadie, sino que se trata de un ser no comprendido, ajeno a la civilización, un excluido. Sin embargo, lo más interesante es ver cómo Cortázar entiende la mitología, con una visión moderna, e incluso, me atrevería a decir, científica, pues se detiene en los perfiles de estos seres vetustos que reflejan las pasiones y sufrimientos del ser humano, que ahora en el siglo XXI todavía reconocemos e identificamos con las nuestras.

No podemos olvidar la gran influencia que tienen, concretamente en la sociedad argentina, las escuelas de la psicología de Freud, desarrolladas por Jung, Kérenyi y Diel, que analizaron el fondo psicológico de muchos de los mitos clásicos ${ }^{13}$. Para Jung

${ }^{9}$ Cortázar (1985:74).

${ }^{10}$ Hay que tener en cuenta que este cuento de Borges está encabezado por una cita de Apolodoro «Y la reina dio a luz un hijo que se llamó Asterión», precisamente la fuente que señalábamos para la obra de Cortázar (Apollod. III, 1,4).

${ }^{11}$ Shaw (1989: 721-724). Para un análisis del mito del minotauro en la obra de Borges véase del Río (2012: 994-998).

${ }^{12}$ En 1993 la novela Lituma en los Andes de Mario Vargas Llosa volverá a retomar el mito del Minotauro, donde éste se entremezcla con la mitología sobre Dioniso, véase de Paco Serrano \& Vásquez Rodríguez (2005:995-909). También podemos observar los ecos de este mito en el cuento del puertorriqueño René Marqués: «Ese mosaico fresco sobre aquel mosaico antiguo». En él el laberinto se convierte en un símbolo fundamental de la trama y la estructura. Para un análisis detenido de las referencias clásicas en el mismo véase Esteban Santos (2007:253-264). Podemos observar, por tanto, que se trata de un mito que ha tenido gran proyección en lo que respecta a la literatura hispanoamericana.

${ }^{13}$ Para una revisión general sobre la interpretación de la mitología véase Ruiz de Elvira, (2011: 32 38) y sobre la interpretación de los mitos del siglo xx véase García Gual (2007:235-258). 
existe un inconsciente colectivo que supone «una parte de la psique que conserva y transmite la común herencia psicológica de la humanidad. Estos símbolos son tan antiguos y desconocidos para el hombre moderno que no puede entenderlos o asimilarlos directamente ${ }^{14}$. Sin embargo, no sólo existieron esos intentos de interpretación científica del mito griego. Debemos reparar en la fecha en la que se publican estos relatos mitológicos de Cortázar: 1949 (Los reyes), 1951 («Circe») y 1956 («Ménades»). En estos años, el mitólogo Robert Graves había publicado The Greek Myths (1955) que desentrañaba lo que el mito podía albergar de la realidad en la que se crearon. Esta visión le hace oponerse a la escuela de Jung, que proponía la búsqueda de la psique preconsciente en estos mitos desordenados, infantiles y caóticos:

Una verdadera ciencia del mito debería comenzar con el estudio de la arqueología, la historia y la religión comparada y no en la consulta del psicoterapeuta. Aunque los defensores de Jung sostienen que «los mitos son revelaciones originales de la psique preconsciente, conclusiones involuntarias sobre los sucesos psíquicos que tienen lugar en el inconsciente», el contenido de la mitología griega no fue más misterioso que las modernas caricaturas electorales, y en su mayor parte los mitos se formularon en territorios que mantenían estrechos contactos políticos con la Creta minoica, un país tan sofisticado que contaba con archivos escritos, edificios de cuatro pisos con higiénicos sistemas de canalización... ${ }^{15}$

Por otro lado, la corriente estructuralista también desarrollará sus propias consideraciones sobre el mito. C. Lévi-Strauss se opone a los postulados de Jung, ya que supone que existen significaciones precisas que están intrínsecamente relacionadas con unos temas o arquetipos; mientras que para Lévi-Strauss el mito era un conjunto de variantes en las que ninguna de ellas alcanzaba un grado de superioridad independientemente de la época en la que se hubieran evocado: «No dudaremos, pues, en colocar a Freud, después de Sófocles, entre nuestras fuentes del mito de Edipo. Sus versiones merecen el mismo crédito que otras más antiguas y en apariencia más auténticas $\rangle^{16}$. Esta estructura, que será concebida por Lévi-Strauss como tridimensional, revelará una serie de repeticiones que cumplirán una función muy clara: manifestar la estructura del mito ${ }^{17}$.

De tal manera, frente a la interpretación mitológica ofrecida por Graves o cualquiera de las otras propuestas que hemos revisado, vemos una clara determinación de Cortázar por la corriente de Jung, que es precisamente la que le sirve para analizar, mediante la literatura, la atemporalidad de estos caracteres míticos. Expresaba Cortázar que la

${ }^{14}$ Henderson (1995: 107).

${ }^{15}$ Graves (2004: 27).

${ }^{16}$ Lévi-Strauss (1995: 229-252).

${ }^{17}$ Propp había utilizado como método de trabajo el estructuralismo con el folclore y la mitología (2009). Esta obra influyó en Levi-Strauss. Propp prosiguió su análisis histórico del material cuentístico (2008). Aunque se trata de posturas complementarias en Strauss \& Propp, (1982:9) se abre un debate sobre ambas: ¿podemos quedarnos en trazar un análisis funcional del argumento como establece Propp o es necesario trascenderlo integrando dicho análisis en una mitología popular? Existe un estudio de Mora Valcárcel (1982: 39-47) que aplica los elementos de análisis cuentístico de Propp y el resto de la escuela estructuralista a los relatos de Cortázar. 
historia le había venido dada en un colectivo, precisamente por la latencia que en él se daba, tal vez desde la propia metáfora onomástica, de una memoria común que le conectaba con las antiguas historias que un archibisabuelo cretense habría vivido ${ }^{18}$.

\section{CASOS CONCRETOS DE RECREACIÓN DE TEMÁTICAS CLÁSICAS EN SUS CUENTOS}

Convocar a los seres mitológicos dentro de una obra literaria supone un ejercicio de adaptación de la materia antigua, que puede darse en distintas direcciones, según las necesidades del autor. Vicente Cristóba ${ }^{19}$ establece que el mito no sólo puede servir para aportar un asunto sobre el que verse la nueva obra, y nos pone por ejemplo el Polifemo de Góngora; sino que puede proporcionar unos personajes, un ambiente que sugieren el mito sobre el que se proyectan las situaciones, que son inventadas y, en el caso de Cortázar, como vamos a establecer, desde una escenografía contemporánea. Este último proceso no surge en el siglo $\mathrm{xx}$, sino que lo vemos como procedimiento de creación literaria, según explica también Vicente Cristóbal, en algunas novelas breves de Apuleyo, como la de la madrastra enamorada, que retoma el mito de Fedra e Hipólito ${ }^{20}$.

De esta forma, Cortázar, apoyándose en la gran latencia que las escuelas de psicología y psicoanálisis habían dejado en su sociedad, y partiendo de este procedimiento antiguo de creación de un argumento ficticio a partir de un esquema clásico, concita a dos personalidades clásicas y les hace despertar para describir un verdadero análisis de sus psicologías.

\section{1. «Circe» de Bestiario: una mirada hacia la Circe homérica}

Este primer relato pertenece a Bestiario $(1951)^{21}$. El texto toma como punto de partida el mito de la maga Circe, hija del $\operatorname{Sol}^{22}$ y de Perseis y hermana de Pasífae, de la

${ }^{18}$ Para una visión de la psicología en la obra de Cortázar y la interpretación psicoanalítica en sus relatos véase Goyalde Palacios (2001: 172-174).

${ }^{19}$ Cristóbal (2000:32-33).

${ }^{20}$ APUL., Met. 10, 2-13.

${ }^{21}$ El relato de «Circe» se sitúa en la etapa anterior al viaje definitivo de Cortázar a París, en la que el autor trabaja con la tradición clásica, como explica Goyalde Palacios (1998:1). En este período realizó su ensayo sobre Píndaro bajo la dirección del profesor Arturo Marasso, véase Alazraki (1994: 49), y un fichero mitológico de Homero y Hesíodo, como explica el propio Cortázar en una pequeña introducción que antecede a su composición Las ruinas de Knossos: «de muchacho tuve una fugaz vocación de helenista, hasta hice un fichero de mitología griega después de leerme todo Homero y Hesíodo, alentado por la bondad y el saber de Arturo Marasso» Cortázar (1985b: 30). Goyalde (1998:113) insiste en la posterior influencia de Keats en su mirada del mundo clásico, dando lugar a trabajos como Cortázar (1946: 1-49) y Cortázar (1996). No hay que olvidar que Cortázar tradujo La naissance de l'Odyssée de Jean Giono. Véase Cortázar (1946). Dentro de estos relatos de inspiración clásica no podemos olvidar «El ídolo de las Cícladas» en Cortázar (2003: 69-79). No trataremos este relato dentro de la búsqueda de caracteres psicológicos míticos, pues el mito se centra en este cuento en el análisis de lo ritual a través de una pieza arqueológica. Para un análisis de este relato véase González de Tobia (2009: 1010-1011).

${ }^{22}$ Sobre la genealogía de las hijas del Sol véase Esteban Santos (2010: 151-173). La autora presenta un bellísimo análisis de las mujeres a las que llama «ardientes mujeres de la raza del sol» en las que determina 
cual ya hemos hablado anteriormente. Respecto a las fuentes mitológicas, cabe mencionar en primer lugar la aparición de su genealogía en la Teogonía de Hesíodo (v. 957), donde aún no se profundiza en el personaje. La segunda referencia la encontramos en la Odisea, en los cantos X y XII, en los que se narra con toda serie de detalles cómo vivía en la isla de Eea y su encuentro con Ulises, que vagaba por los mares

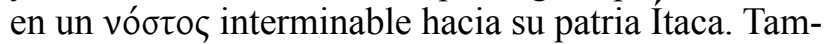
bién aparece el mito narrado en los Argonautica de Apolonio de Rodas (4, 659-752) y en la Biblioteca de Apolodoro (I, 9,1). Incluso, vemos un tratamiento cómico del mismo en Pluto de Aristófanes (vv. 302308). Dentro de la literatura latina cabe destacar su aparición en las Metamorfosis de Ovidio (14, 1-74), que pudo influir en Cortázar. La iconografía nos muestra a Circe desde época temprana y no ha dejado de seducir a la musa de otros pintores contemporáneos como John William Waterhouse (Fig. 2).

Sin embargo, ante el relato homérico, cualquiera de las fuentes queda ensombrecida. Además no cabe duda alguna de que Cortázar se dejó seducir por la Odisea, la cual fue dejando un poso en él que sería el punto de partida para la creación de esta excelente pintura de la Circe contemporánea.

El relato de Homero se enmarca dentro de los viajes de Ulises, una vez que llega a la isla de Eea empujado por los vientos que ya no le eran favorables. Tras haberse dividido en dos grupos y haberlo echado a suertes, se decide que Euríloco y la mitad de la tripulación inspeccione el espeso encinar del que se veía salir un humo. Allí descubrirán el palacio de la maga

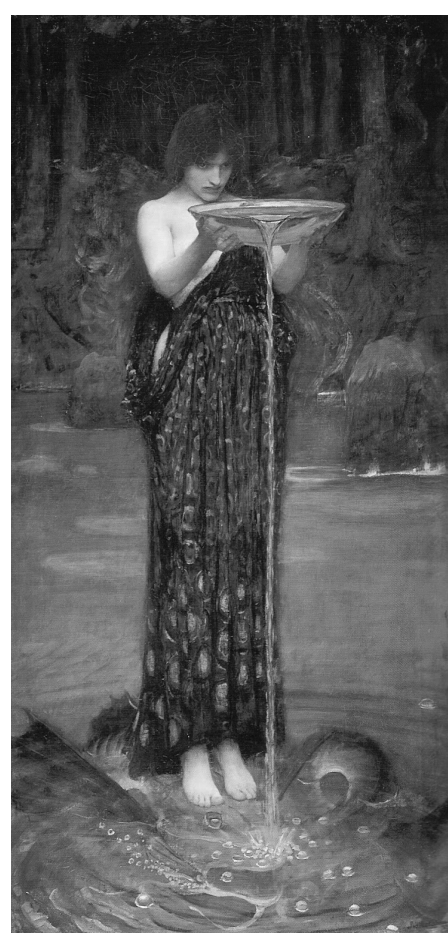

Fig. 2. Circe invidiosa, 1891.

J.W.Waterhouse.

Óleo sobre lienzo. Art Gallery of S.Australia Circe, en el que todos se adentrarán inocentemente y serán transformados en cerdos por la acción del brebaje entregado por la bruja. Sólo Euríloco, sospechando el engaño, no se adentra en el palacio, lo que hace posible que acuda en busca de Ulises. Éste, al enterarse de lo acaecido, se dirige al palacio, pero en el camino Hermes lo detiene y, tras explicarle cómo debe enfrentarse al plan de Circe, le ofrece la planta $\mu \tilde{\omega} \lambda v$ que le protegerá de los bebedizos de la malvada maga. Odiseo se salvará así de la metamorfosis en cerdo y, amenazando a la bruja, conseguirá la restauración de la primera forma de sus compañeros de viaje. De tal manera que, tras compartir el lecho con ella durante un año, retoma su viaje hacia Ítaca.

una serie de características psicológicas, que nos interesan por reflejarse en la Circe homérica y algunas en la creada por Cortázar: mujeres apasionadas que llevan la iniciativa en el amor, posesivas, celosas, traidoras, desmesuradas, sabias e incluso con poderes mágicos, que infunden miedo a todos los que las rodean. Esta casta estaría constituida por tres generaciones: $1^{\mathrm{a}}$ Generación (Hermanas de Helio: Eos y Selene), 2. ${ }^{\mathrm{a}}$ Genera-

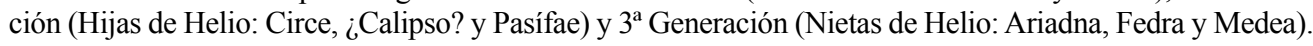


El cuento de Cortázar no se encuadra en ningún viaje mítico, sino en la pura cotidianidad, como ya hemos explicado. El relato se presenta en boca de un narrador omnisciente $^{23}$, que conoce o cree conocer perfectamente la historia de la protagonista: los dos últimos novios de Delia habían muerto accidentalmente. Sin embargo, su actual pareja, Mario, no sospechaba nada y se rinde a la presencia de Delia. Se trata de un narrador no identificado y un tanto amnésico ( «Yo me acuerdo mal de Delia pero era...» pág. 86 «Yo me acuerdo mal de Mario, pero dicen que...» pág. 88). Incluso dice que las historias se contaminan con «falsedades mínimas que se tejen y tejen por detrás con los recuerdos» (pág. 92). No podemos olvidar este «tejen y tejen», que retomaremos más adelante aludiendo al proceso mental de Mario, y su similitud con expresiones referidas a Ulises.

Este narrador sólo va dando pinceladas, pistas que nos van conduciendo hasta donde él quiere llevar al lector: la culpabilidad de Delia. En primer lugar conocemos los rumores de los vecinos que creen culpable a Delia de algún terrible crimen ${ }^{24}$, que nosotros aún desconocemos («no porque yo lo crea, pero si fuese verdad qué horrible» pág. $85^{25}$ ); aunque poco después el narrador es sentencioso: «Y cuando volvía del trabajo entraba ostensiblemente para saludar a los Mañara y acercarse - a veces con caramelos o un libro -a la muchacha que había matado a sus dos novios» ${ }^{26}$ (pág. 86, cursiva mía).

${ }^{23}$ «En el cuento, el objeto focalizado es un proceso mental, Mario no incorpora voces, Mario focaliza, en el sentido de que, siendo el único personaje que verbaliza la actividad de su conciencia, puede interpretar, reconstruir las voces de otros, principalmente la voz de Circe-Delia, la voz-tapiz de Delia...» Liñares (1999: 105-114). No hay que olvidar que el relato de las aventuras en la isla de Circe forma parte de las historias narradas por Ulises en el país de los feacios por lo que el relato está en $1^{\text {a }}$ persona, dejando en estilo directo las palabras de Circe. En el caso de Cortázar, el juego que evidencia el poder del narrador para contar la historia y llegar a dirigir al lector hasta un veredicto determinado, constituye una técnica muy utilizada en su obra. Le interesa mostrar cuán poderoso es el narrador, hasta qué punto su versión es la única. Así por ejemplo en «Cartas de mamá» (Cortázar, 2010:69-93) llegamos a dudar de quién dice la verdad: si el narrador (focalizado en el proceso mental de Luis) o Laura (vista por el narrador como un personaje de actuación extraña para él). De tal manera que en "Circe», al privar casi totalmente a Delia de voz, toda nuestra visión del personaje parte del proceso mental de Mario, que finalmente corrobora las sospechas de todos los vecinos. Para una visión del papel de cada personaje en el cuento de "Cartas de mamá» véase de Mora Valcárcel (1982:204-205).

${ }^{24}$ La versión cinematográfica homónima del cuento, Circe (1964), dirigida por Manuel Antín y en cuya versión participó el propio Cortázar, muestra a una Delia que se siente culpable y a la que le afectan los rumores de los vecinos y la presencia de sus exnovios fallecidos que la atormentan: «Delia: en momentos cuando estoy con vos, sobre todo cuando estoy con vos, en que es como un peso, una carga, no la llamemos culpa, si querés, pero está en esta casa, en mis padres, pegado a mi ropa». Sin embargo, en el cuento de Cortázar no se profundiza en los sentimientos de Delia, sino que se nos ofrece, más bien, una visión de lo que se piensa de Delia y lo que se dice de ella, pero no se detiene a describir los sentimientos de esta Circe. Su doble condición se mantiene en la película e incluso la vemos besando su reflejo en el espejo y sonriendo, como en el caso del cuento.

${ }^{25}$ Cito todos los ejemplos de «Circe» a partir de Cortázar (2003: 85-107).

${ }^{26}$ Los dos crímenes de los que se culpa a Delia y que tienen lugar antes de la seducción de Mario, el suicidio de Héctor y el golpe mortal en la cabeza de Rolo (examantes ambos de Delia), parecen reforzar la caracterización psicopática de ésta, que en la Circe de Homero se reducía a un halo de misterio que cubría al personaje a través de la aparición de los hombres zoomórficos, afectados por sus hechizos. Goyalde (1998:115) señala que la atmósfera que crea estas alusiones veladas a los anteriores asesinatos debe ser entendida en el contexto de las lecturas hechas por Cortázar de Keats y Rossetti. Hay que recordar que 
Uno de los rasgos más destacados sería cómo Cortázar caracteriza a Delia con los mismos rasgos físicos y psíquicos de femme fatale que encontramos en $\mathrm{Circe}^{27}$. Es decir, Delia se caracteriza por su belleza al igual que Circe. En el relato cortaciano se nos

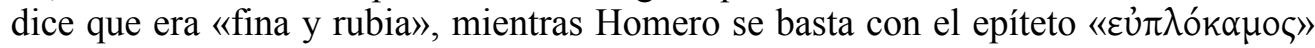
$(10,136)^{28}$, es decir, 'de cabellos bien rizados'o 'de hermosos rizos'. Parece, por tanto, que sus cabellos contribuyen en buena parte a esta seducción fatal. Sin embargo hay algo más, que se sitúa entre lo terrible y lo seductor, que hace que Delia y Circe consigan obtener lo que desean del resto de los seres humanos. En primer lugar, Circe parece seducir con la voz. Son numerosas las referencias que se hacen a la misma:

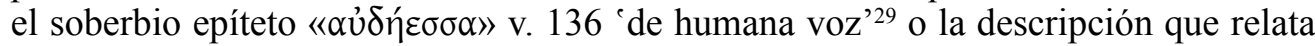

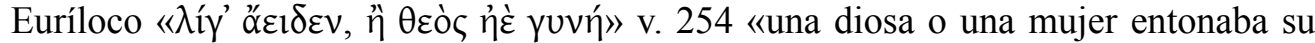
canto sonoro $\rangle^{30}$. Este rasgo seductor podría asemejarse a otro que se nos da de Delia, también referido a la música: «un día tocó el piano» (pág. 90), «tener un novio tan delicado, Mario comprendía ahora la liberación que asomaba en los gestos, en la manera de tocar el piano de Delia» (pág. 94). «Ella tocó el piano, como casi nunca ahora, y le pidió que volviera al otro día. Nunca habían hablado con esa voz, nunca se habían callado así» (pág. 95). Observamos además que en torno a la voz de Delia existe siempre un halo de misterio. La aparición reducida del discurso directo en general y la profundización en los pensamientos de Mario y no de Delia, hacen que las pocas palabras proferidas por ella se hagan especiales para el lector y, en cierta manera, sentenciosas, como veremos claramente en su augurio de la muerte del pez. Incluso la descripción de su forma de expresarse refuerza en ocasiones lo extraordinario de esta voz: «Hizo un gesto como para abrir una puertecita en el aire, un ademán casi mágico. —Entonces sos mi novio — dijo—. Qué distinto me parecés, qué cambiado» (pág. 99).

este cuento incluye, con el título, una cita de «The Orchard-Pit» de Rossetti, donde se concitan muerte y seducción. Se trata de una mujer que atrae al hombre con sus cantos de sirena y le ofrece una manzana envenenada, que conduce al hombre a la muerte. Es evidente la simbología erótica, al igual que en los bombones que ofrece Delia a Mario y que resultan contener una cucaracha. Sin embargo, Mario, al igual que Odiseo, se libra de la muerte y de los venenos de Delia, en este caso sin necesidad de ninguna protección divina ni de ninguna planta $\mu \tilde{\omega} \lambda v$.

${ }^{27}$ Para un estudio sobre la relación de la Circe homérica con la femme fatale véase Aguirre Castro (1994: 301-317). En él se señalan los elementos comunes de Circe con Calipso en su relación con el

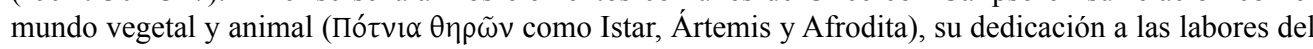
hogar (La Gran Diosa Madre del Mediterráneo oriental tenía el huso y la lanzadera como atributos ya que dominaba la vida salvaje y la doméstica), en la seducción de Odiseo que les sirve a Circe y Calipso para retenerlo (son mujeres fatales vencidas por el héroe, al igual que el canto de las Sirenas). Para un estudio pormenorizado en el que se trazan paralelos entre ambas diosas fatales véase Crane (1988: 124-134). El personaje de Delia de Cortázar dentro del paradigma de la femme fatale ha sido estudiado detenidamente en Houvenaghel \& Monballieu (2008: 853-866).

${ }^{28}$ Cito todos los pasajes en griego de la Odisea a partir de la edición de Allen, Oxford 1966.

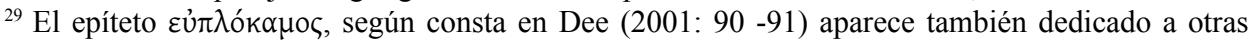
diosas femeninas, como Atenea o Calipso (con la que la diosa de Eea se relaciona íntimamente) a las que se les podría aplicar una cierta fortaleza o independencia respecto de los varones, a los que en muchas ocasiones dominan o lo intentan. Puede aparecer en compañía de $\delta \varepsilon ı v ́$ ('terrible') como se ve en secuen-

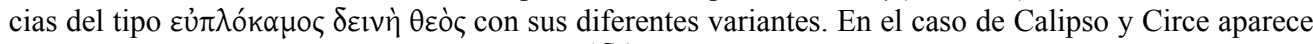

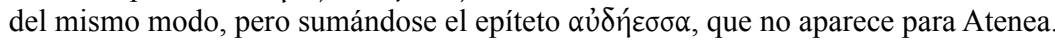

${ }^{30}$ Cito todos los pasajes en español a partir de la traducción de J. M. Pabón. 
En segundo lugar, otro rasgo que parece seducir a los pretendientes, en ambos casos, es su caracterización como habilidosas amas de casa. En ambos textos se nos las

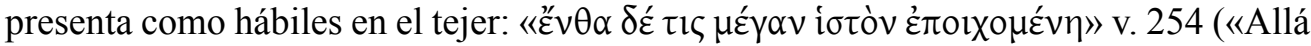
dentro labraba en ingente telar») nos dice Homero, mientras que Cortázar explica: «era más dulce con Mario, lo hacía sentarse cerca de la ventana de la sala y le explicaba proyectos de costura o de bordado» (pág. 90 cursiva mía) ${ }^{31}$.

Otro elemento que tiene que ver con esta laboriosidad sería la propia preparación de bombones y licores por parte de Delia. Circe también prepara sus brebajes e incluso hace que sus misteriosas sirvientas, a las que me referiré posteriormente, les sirvan comida: «Con un jarro de oro llegaba después una sierva que en mis manos el agua vertió sobre fuente de plata y me puso delante una mesa bruñida; la honrada despensera, trayéndome el pan, colocólo a mi lado, presentóme otros manjares que en casa tenía y me instó a que comiera...» (vv. 368-373). Sin embargo, esta relación con la comida y la bebida está ya intrínsecamente relacionada con el arma de posesión más patente de ambas mujeres: la magia.

De tal manera, como tercer elemento, debo pasar a analizar detenidamente cómo se inserta en cada uno de los relatos lo mágico o brujo, que provoca miedo y sospecha en todos los que las rodean. Para Homero no supone un problema el introducir el elemento mágico de forma clara y concreta, la única duda se presenta en saber si,

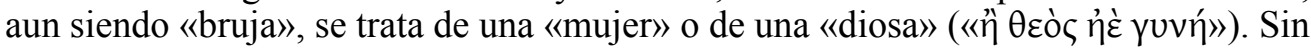
embargo, parece que esta vacilación entre su verdadera naturaleza nos es presentada por Homero como otro rasgo añadido de caracterización del personaje. Es decir, se trata de una diosa, esto ya debería poner en alerta a cualquier mortal (¡Piénsese en las venganzas de Hera y Atenea!), que esconde su apariencia divina bajo su «humana voz», epíteto que citaba supra. Por lo tanto se trata de una personalidad que encubre su

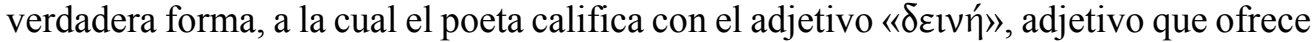
múltiples interpretaciones desde 'potente o poderoso' por la que se decanta José M. ${ }^{a}$

${ }^{31}$ Es interesante tener en cuenta las consideraciones que expone sobre el tejer Gualerzi (2007: 123151). Tanto en el caso de Circe como en el de Calipso las tareas domésticas en torno al telar, junto al canto, pretenden crear un clima de tranquilidad y seguridad que encubran las posibles sospechas del varón respecto a estas mujeres temibles y seductoras, que ocultan bajo esta máscara, junto a la de la belleza, toda su maldad. Es decir, un elemento que se relaciona, en primera instancia, a un entorno doméstico tranquilo y estable para el hombre (Véase la figura de Penélope en Felson-Rubin, 1994: 16-42), pasa a encubrir a estas antiguas figuras de las femmes fatales. De esta manera Cortázar presenta a Delia creando proyectos de costura y cantando para crear un ambiente que seduzca a Mario, a pesar de lo expuesto por Liñares (1999: 111). La autora establece «faltan dos elementos específicos: no está su voz; no está su tejido». Sin embargo, sus proyectos de costura se refieren junto con su actividad musical (el piano). Sí es verdad que se utilizan expresiones referentes a la costura y al tejer para hablar del proceso intelectivo de Mario, al igual que Ulises, pero no puede analizarse de ningún modo como una «transposición» de lo homérico en este sentido, que según la autora da lugar a que «la labor del tejido esté a cargo del personaje de Mario». La «labor del tejido» está en Delia como realidad, pues así lo establece la propia descripción del texto («le explicaba proyectos de costura o de bordado» pág. 90) y en Mario, como ya hemos señalado antes, metafóricamente al igual que en el v́paív $\omega$ homérico («Mario juntaba pedazos de episodios, se descubría urdiendo explicaciones paralelas al ataque de los vecinos» pág. 90, cursiva mía). 
Pabón en su traducción de la Odisea; pero además podría significar 'terrible ${ }^{32}$. Creo que esta dualidad también es presentada por Cortázar muy sabiamente, entre la visión que los demás ofrecen de Delia, y la carencia de pruebas que corroboren lo supuesto. Es decir, las acciones que prueban una conducta terrible por parte de Delia, se limitan a pequeños guiños, pinceladas sutiles que el narrador nos va dejando entrever. Por ejemplo, cuando nos confiesa, como si quisiera mandarnos también a nosotros un anónimo: «Era penoso presenciar la sonrisa velada de Delia cuando se ponía el sombrero ante el espejo, tan rubia sobre el luto» (pág. 87). Aquí son estas prendas de luto las que esconden con su negro, las que manifiestan un supuesto sufrimiento por parte de la joven, las que de alguna manera, la exculpan ante el lector. Es decir, son éstas, como la voz humana de Homero, las que cubren su rubio de femme fatal. Incluso se llega a afirmar «Algo le decía a Mario que Delia iba a conseguir cosas maravillosas con los bombones (pág. 94, cursiva mía). Vemos en este maravillosas

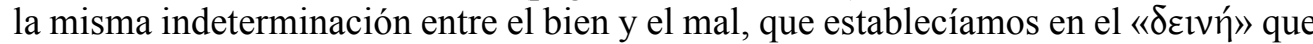
emplea Homero.

Adentrándonos ya más en el aspecto de la brujería, vemos que Homero nos lo muestra explícitamente, pues escribe dentro del género épico en el que estos elementos no desentonan. Por tanto, desde el principio nos muestra a una Circe que domina a la naturaleza de su isla, a la que ha sometido. Además se nos da a entender que los animales salvajes en otro tiempo fueron hombres, antes de sufrir la magia de Circe que los transformó. Incluso, en los Argonautica de Apolonio de Rodas (4, 672-5) los animales aparecen como seres híbridos de hombres y animales, remarcando así que son fruto de un hechizo de Circe. Creo que es muy representativo este fragmento de la Odisea en el que se ve a Circe entre sus fieras a las que controla:

Encontraron las casas de Circe fabricadas con piedras pulidas en sitio abrigado; allá fuera veíanse leones y lobos monteses hechizados por ella con mal bebedizo: se alzaron al llegar mis amigos y en vez de atacarlos vinieron a halagarlos en torno moviendo las colas. Al modo que festejan los perros a un rey que deja el banquete porque siempre les lleva un bocado gustoso, así ellos coleaban, leones y lobos de fuertes pezuñas (vv. 210-218).

${ }^{32}$ Se trata de un adjetivo que se suele referir a monstruos que por su propia apariencia son terri-

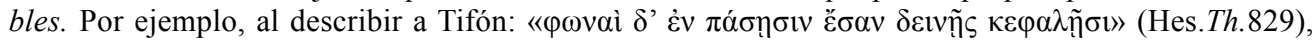
«había tonos de voz en aquellas terribles cabezas». Es decir, monstruos que espantan por su aspecto

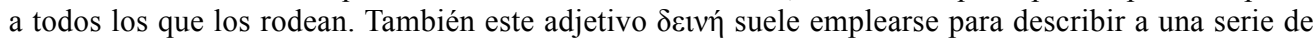
mujeres, varias de las que hemos englobado antes dentro de la genealogía del Sol, que no infunden el miedo por su aspecto terrible, sino que ocultan su maldad, e incluso su poder, bajo una seducción que venimos describiendo a lo largo de todo el trabajo. Se trata de mujeres que tiene poderes mágicos y son consideradas sabias en sus artes (Medea, Calipso, Circe etc.). Todos sospechan de sus actos y temen que empleen su sabiduría para hacer el mal. Este sentido se vería reflejado perfectamente en las

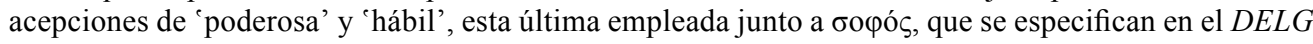
(sub voce). 
Por el contrario, diremos que a Cortázar el no insertar la magia como evidencia ${ }^{33}$, le sirve como instrumento para seguir haciendo al lector dudar del veredicto que debe dar de Delia. Tenemos muestras de elementos que parecen sobrenaturales ${ }^{34}$, más concretamente que parecen pertenecer a algún tipo de magia negra. La primera nota de esta dominación, que ejerce de un modo que se acerca a lo mágico, sería la relación que Delia establece con los animales: parecen domesticados ante su presencia como si

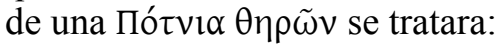

Un gato seguía a Delia, no se sabía si era cariño o dominación, le andaban cerca sin que ella los mirara. Mario notó una vez que un perro se apartaba cuando Delia iba a acariciarlo. Ella lo llamó (era en el Once, de tarde) y el perro vino manso, tal vez contento, hasta sus dedos. La madre decía que Delia había jugado con arañas cuando chiquita. Todos se asombraban, hasta Mario que les tenía poco miedo. Y las mariposas venían a su pelo - Mario vio dos en una sola tarde, en San Isidro-, pero Delia las ahuyentaba con un gesto liviano (pág. 87).

E incluso les produce la muerte: «Héctor le había regalado un conejo blanco, que murió pronto, antes que Héctor» (pág. 87). No podemos olvidar al felino que aparece

${ }^{33}$ «Lo fantástico se crea esencialmente a partir de lo eludido: de esos vacíos que pueden atribuirse al narrador y a su saber (su falta de saber) pero que tal vez se abran en la urdimbre misma de la historia.» Campra (2009: 55).

${ }^{34}$ En otros casos no es ya lo «eludido» que puede hacernos pensar en realidades de tipo paranormal, sino una sugerencia a través del léxico de lo mágico. Como señala Goyalde (1998:117), aunque Cortázar niega que Delia sea un precedente de la Maga de Rayuela, existen ciertos elementos que las identifican. Es precisamente en la descripción de la relación que mantiene con los gatos donde se sugiere con mayor similitud, recurriendo a un léxico referente a lo mágico y misterioso: «y los gatos, siempre inevitablemente los minouche morrongos miaumiau kitten kat chat gatto grises y blancos y negros y de albañal, dueños del tiempo y de las baldosas tibias, invariables amigos de la Maga que sabía hacerles cosquillas en la barriga y les hablaba un lenguaje entre tonto y misterioso, con citas a plazo fijo consejos y advertencias» Cortázar (2010: 146). Ya desde el juego con los nombres de gato, en distintas lenguas y registros, se nos lleva al mundo de las palabras mágicas, de la brujería que esta Maga parece ejercer en los gatos a través de palabras que se describen como «misteriosas», sin permitir que el lector las escuche, creando así, desde la «elusión», una sospecha aún mayor por la realidad del mundo cortaciano. En nuestro caso es interesante ver cómo al igual que la realidad cotidiana se muestra llena de sugerencias mágicas: lo mítico se transforma en cotidiano en su Circe. Se trata por tanto de un juego de doble enfoque. No podemos olvidar cómo lo erótico se sugiere a partir de lo mítico y monstruoso en el bellísimo capítulo 7 de Rayuela: «Me miras, de cerca me miras, cada vez más de cerca y entonces jugamos al cíclope, nos miramos cada vez más de cerca y los ojos se agrandan, se acercan entre sí, se superponen y los cíclopes se miran respirando confundidos, las bocas se encuentran y luchan tibiamente...» Cortázar (2010:160). Este juego entre lo mítico y lo cotidiano se da también, como expondré más detenidamente en un estudio en preparación, en el capítulo 20 de Rayuela, donde la Maga y Oliveira se despiden entre lágrimas y risas, acompañados de su hijo enfermo Rocamadour. Es evidente, aunque parece no haber sido señalada por la crítica, la influencia en este pasaje de la despedida de Héctor y Andrómaca del Canto VI de Ilíada (vv. 392-493): «-Probablemente. Fíjate, de todas maneras que si me voy ahora cometo algo que se parece casi al heroísmo, es decir que te dejo sola, sin plata y con tu hijo enfermo. - Sí — dijo la Maga sonriendo homéricamente entre lágrimas - . Es casi heroico, cierto» Cortázar (2010:220). Vemos así que Cortázar también juega con un pasaje mítico no mágico, sino humano, y la realidad contemporánea de sus personajes. 
maltrecho al final del cuento. Sin embargo, en otras ocasiones sólo podemos afirmar que augura su muerte:

—El pez de color está tan triste — dijo Delia, mostrándole el bocal con piedritas y falsas vegetaciones. Un pececillo rosa translúcido dormitaba con un acompasado movimiento de la boca. Su ojo frío miraba a Mario como una perla viva. Mario pensó en el ojo salado como una lágrima que resbalaría entre los dientes al mascarlo.

- Hay que renovarle más seguido el agua — propuso.

-Es inútil, está viejo y enfermo. Mañana se va a morir.

A él le sonó el anuncio como un retorno a lo peor (pág. 98).

Esta capacidad adivinatoria hay que ponerla en relación con la Circe de Homero que predice a Ulises futuros acontecimientos de su viaje ( $O d .10,490 \mathrm{y}$ ss.).

Es más, el que ya tuviera establecida esta relación con los animales desde pequeña, concretamente con las arañas, nos muestra que era algo con lo que había nacido, una especie de don y, por lo tanto, muy cercano a la magia; pero lo suficientemente lejano como para que no resulte inverosímil en la realidad contemporánea. Todo podría ser fruto de las obsesiones de las mentes de los personajes: «Muchos conejos languidecen y mueren en las casas, en los patios. Muchos perros rehúyen o aceptan las caricias» (pág. 89).

El segundo elemento dentro de la caracterización como brujas sería la propia elaboración de pócimas, brebajes, licores o filtros que sirven para controlar a sus víctimas, transformarlas, o causarles la muerte. Como ya hemos mencionado antes, Homero deja claro desde el principio que Circe controlaba a aquellas bestias que la rodeaban, porque en realidad se trataba de hombres que habían sido metamorfoseados como

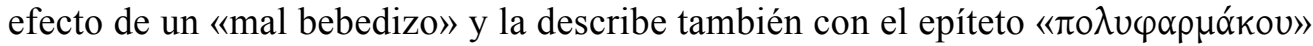
v. 276 'rica en venenos'. Incluso se llega a describir cómo se llevan a cabo las transformaciones:

Ya en casa los hizo sentar por sillones y sillas y, ofreciéndoles queso y harina y miel verde y un vino generoso de Prammo, les dio con aquellos manjares un perverso licor que olvidar les hiciera la patria. Una vez se lo dio, lo bebieron de un sorbo y, al punto, les pegó con su vara y llevólos allá a las zahúrdas: ya tenían la cabeza y la voz y los pelos de cerdos y aun la entera figura, guardando su mente de hombres $(O d ., 10,233-$ 240, cursiva mía).

Posteriormente, cuando Circe intenta envenenar al ya prevenido Ulises, se vuelve a mostrar la elaboración de la pócima: «y mezcló en una copa de oro un brebaje agregando venenoso licor: meditaba en su ánimo el crimen» (vv. 316-317, cursiva mía).

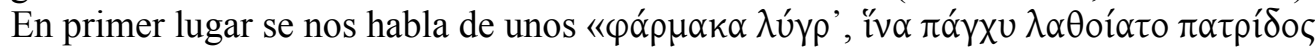

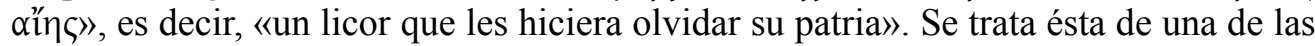
técnicas de posesión más empleadas: el olvido. Habría que recordar, llegados a este punto, la aventura de Ulises en el país de los lotófagos o el canto de las sirenas que seducía y hacía que el navegante no quisiera volver a su patria, olvidando a esposas, padres e hijos. Emplea además Circe otro atributo propio de una bruja, para golpear- 
los: «ṕó $\beta \delta \omega »$ («con una vara»), dotada de poderes mágicos. Incluso en el momento en el que intenta hechizar a Ulises, que gracias al efecto de $\mu \tilde{\omega} \lambda \nu$ se muestra inmune, insiste en su hechizo con una orden que se ajusta al código de los conjuros o palabras

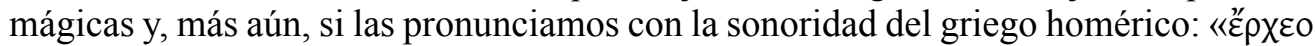

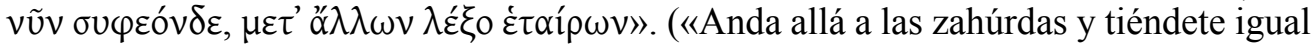
que los otros»).

Veamos ahora qué hace Cortázar con este material, que evidentemente ha de desembrujar para introducirlo en la contemporaneidad de la rutina de su historia. Sin embargo, no renuncia Cortázar a todo el elemento mágico; sino que lo inserta de modo que se ajuste a lo verosímil. Es decir, de modo que se pueda pensar que los experimentos son fruto de la propia obsesión de Delia por controlar a todos los hombres que la rodean. Se nos llega incluso a describir el laboratorio personal de Delia, como si de la mismísima Celestina se tratara: «y él compraba las sustancias para los licores, los filtros y embudos que ella recibía con una grave satisfacción» (pág. 92). La elaboración y el contenido de los bombones también nos van siendo descritos, haciendo que algo tan cotidiano como un bombón resulte mágico por los colores, los sonidos y los gustos que la descripción nos sugiere. Se trata de introducir todos los sentidos que intervienen en la cocina: «Su mejor receta eran unos bombones a la naranja rellenos de licor, con una aguja perforó uno de los que traía Mario para mostrarle cómo se los manipulaba...» (Pág. 91) «Mario obediente cerró los ojos y adivinó un sabor a mandarina, levísimo, viniendo desde lo más hondo del chocolate. Sus dientes desmenuzaban trocitos crocantes, no alcanzó a sentir su sabor y era sólo la sensación agradable de encontrar un apoyo entre esa pulpa dulce y esquiva» (pág. 94).

El cuarto y último elemento que sirve como arma de posesión a estas dos mujeres será la seducción, el erotismo propiamente dicho. Aunque no encontremos en este episodio de la Odisea escenas que podamos calificar como eróticas explícitamente, sí observamos, en los servicios con los que ella le honra al llegar a la isla, ciertas notas que podrían sugerirlo indirectamente. Podemos ver cómo lo baña al llegar, no siendo una criada: «invitóme a ir al baño y, sacando aquella agua en hervor, con la fría la mezclaba a placer; sobre mí por cabeza y por hombros la vertió y el cansancio roedor extirpó de mis miembros» (vv. 360-363). Incluso dice que lo unge con aceites. Más explícitas son, por supuesto, las palabras de la bruja que habían sido predichas por Hermes: «sin tardanza a mi lecho subamos los dos, porque unidos en descanso y amor confiemos el uno en el otro» (vv. 334-335). Sin embargo, Ulises ya venía alertado de que podría querer quitarle en el lecho el vigor y la fuerza. Cortázar acentúa mucho más estas sugerencias y las hace mucho más explícitas. Obsérvese, por ejemplo este fragmento: «Ella hizo algo que nunca antes, le pasó los brazos por el cuello y lo besó en la mejilla. Su boca olía despacito a menta. Mario cerró los ojos llevado por la necesidad de sentir el perfume y el sabor desde debajo de los párpados. Y el beso volvió, más duro y quejándose» (pág. 95). Sin embargo, la que será la más erótica de todas las descripciones del relato tendrá que ver con la cata del último bombón preparado por Delia, como si de un afrodisíaco o excitante se tratara. Atiéndase a la acumulación del léxico relacionado con la culminación del placer sexual (lo introduzco en cursiva): 
Sostuvo con dos dedos el bombón, con Delia a su lado esperando el veredicto, anhelosa la respiración, como si todo dependiera de eso, sin hablar pero urgiéndolo con el gesto, los ojos crecidos - o era la sombra de la sala-, oscilando apenas el cuerpo al jadear, porque ahora era casi un jadeo cuando Mario acercó el bombón a la boca, iba a morder, bajaba la mano y Delia gemía como si en medio de un placer infinito se sintiera de pronto frustrada. Con la mano libre apretó apenas los flancos del bombón, pero no lo miraba, tenía los ojos en Delia y la cara de yeso, un pierrot repugnante en la penumbra (pág. 93).

Esta culminación del placer sexual nos es descrita en este fragmento, cuando las relaciones sexuales entre Mario y Delia no han sido explicitadas en ningún momento en el relato, a diferencia de los ya citados versos de Odisea, en los que Circe invita a Ulises a su lecho para que se unan en «amor y descanso». En Delia vemos una especie de rechazo por el contacto físico («Y el beso volvió, más duro y quejándose» pág. 95, «una vez quiso besarla, la sintió contraerse poco a poco» pág. 103), mientras que su verdadero placer parece obtenerlo de estas perversidades.

Una vez acabado el análisis de las técnicas que Delia emplea para poseer a los demás, o más concretamente a Mario, quisiera comentar muy brevemente cuál es la actitud de Mario y cómo contrasta con la del resto. Mario se ve desde el principio del relato sometido a Delia, lo que le hace renunciar a su familia y a sus vecinos que sospechan de ella y la creen culpable de las muertes de sus anteriores novios. Él, por su parte, cree que la odian porque no es «chusma» como ellos. Ni sus propias sospechas y alucinaciones (recuérdese el momento en el que ve cómo el bombón que está comiéndose Delia se transforma en un ratón), ni las conversaciones con sus padres, los Mañara, logran convencerlo. Ni siquiera son determinantes los anónimos que recibe alertándole de la maldad de su novia, un recorte de un periódico que hablaba sobre la muerte de Héctor: «sólo una honda desesperación pudo arrastrarlo al suicidio, según declaraciones familiares» (pág. 100), o una nota que decía: «yo que usted tendría cuidado con el escalón de la cancel» (pág. 100). Estos anónimos no los toma en serio, incluso piensa si los habría escrito su propia familia, que se mostraba en contra de la relación. No es que en Homero no encontremos esta misma situación; sino que Ulises cuenta con una ventaja que la épica puede permitirse: la ayuda divina del dios Hermes. Éste le aconseja como dios mensajero, sin necesidad de estos anónimos, y le ayuda a protegerse de los poderes de la bruja con el antídoto $\mu \tilde{\omega} \lambda \nu$ y el consejo de hacer jurar a Circe por la Éstige, juramento inquebrantable, que no intentaría herirle con engaño mientras yacía con ella.

Por otro lado, la familia de Delia vive asustada, como lo estaba el antiguo vecindario donde vivían, por lo que deciden mudarse. Los Mañara no reciben visitas, aunque sospechan de su hija claramente, como se ve en el gesto de no querer probar los licores que prepara. Otro detalle muy claro lo percibimos en el momento en el que Delia no quiere darle el licor a Mario porque dice que es para mujeres, entonces la madre sólo es capaz de iniciar la frase "A Héctor...» y se entrecorta por el llanto (pág. 90). Está claro que los padres saben lo que ocurre aunque deben mantenerse callados, incluso el padre se reúne a solas con Mario, pero éste no logra entenderlo, pues está absorto en esta posesión mágica, como si Delia ejerciera un control abso- 
luto de su mente, aun fuera de la casa. La Circe homérica también inspira miedo a quienes la rodean, no hay más que observar que vive también sola en una isla apartada, en compañía de cuatro criadas a las que Homero, o tal vez la propia Circe, no cede la palabra en ningún momento. Sin embargo, en el caso de Delia, el embrujo se rompe sólo con la visión del contenido del último bombón a la luz de la luna: una cucaracha triturada. Lo prueba ya sin venda en los ojos. De tal manera que se enfrenta a ella e intenta ahogarla. Habría que recordar aquí cómo Ulises amenaza a la bruja Circe con un cuchillo para salvarse (véase $O d$., 10, 321-322). En la escena en la que intenta matarla, los Mañara parecen esconderse, parecen estar ansiosos de acabar con aquella personalidad que los poseía...

La luna cayó de plano en la masa blanquecina de la cucaracha, el cuerpo desnudo de su revestimiento coriáceo, y alrededor, mezclados con la menta y el mazapán, los trocitos de patas y alas, el polvillo del caparacho triturado. Cuando le tiró los pedazos a la cara, Delia se tapó los ojos y empezó a sollozar, jadeando en un hipo que la ahogaba, cada vez más agudo el llanto, como la noche de Rolo; entonces los dedos de Mario se cerraron en su garganta como para protegerla de ese horror que le subía del pecho, un borborigmo de lloro y quejido, con risas quebradas por retorcimientos, pero él quería solamente que se callara y apretaba para que solamente se callara [...] Estaba seguro de que los Mañara habían oído y estaban ahí contra la puerta, en la sombra del comedor, oyendo cómo él hacía callar a Delia (págs. 105$106)^{35}$.

\section{2. «Ménades» de Final de Juego: un nuevo grito de «evohé»»}

El relato que ahora nos ocupa fue publicado en Final del juego (1956). Se trata de un cuento inspirado en el denominado $\beta \alpha \kappa \chi \varepsilon v ́ \sigma \mu o v$, 'el furor báquico'. En primer lu-

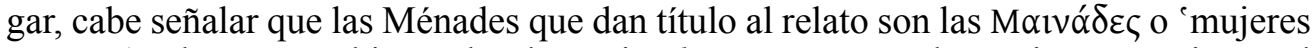
posesas', a las que también se las denomina bacantes por ser las mujeres que siguen al

${ }^{35}$ Oviedo Pérez de Tudela establece (1996: 371-379), entre otras muchas conexiones del surrealismo con la narrativa de Cortázar, las obsesiones internas que luchan por salir y que terminan en una catarsis, representada, en este caso, por la cucaracha que aparece dentro del bombón. Esta imagen es plenamente surrealista. Una obsesión interna muy similar se puede observar también en los conejitos que atormentan al protagonista de «Carta a una señorita en París». Cortázar (2003:23-37). La bibliografía sobre el surrealismo en relación con la obra de Julio Cortázar es muy amplia: Picon Garfield (1975) y Goyalde (2001b: 244-246). Esta última obra (pág. 46) establece que el relato de «Circe», según el propio autor señala en diversas fuentes, le fue inspirado por el temor obsesivo de acabar encontrándose con un insecto en la comida. Es decir, intenta buscar una interpretación biográfica para la génesis del relato.

${ }^{36}$ Goyalde Palacios (2001: 35-42) señala que la referencia a Ménades en la obra de Julio Cortázar es muy abundante. Así por ejemplo en el capítulo 68 de Rayuela, emplea el grito de las Ménades «¡Evohé!», para insertarlo en su nuevo idioma el «glíglico», donde consigue crear una escena de gran erotismo a partir de la fonética de palabras sin sentido. Podemos señalar una posible influencia, en este aspecto de la lengua inventada, de los experimentos poéticos de Lewis Carroll (1997) y los de Huidobro en el Canto VII de Altazor (2011: 137-138). 
dios $\mathrm{Baco}^{37}$. La palabra Ménades procede del verbo grie-

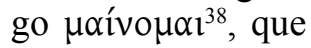
quiere decir 'estar furioso o rabioso, estar loco, fuera de sí, cegado...' Estas mujeres son la «personificación de los espíritus orgiásticos de la Naturaleza» ${ }^{39}$. Debemos diferenciar entre las Ménades como divinidades y aquellas mujeres,

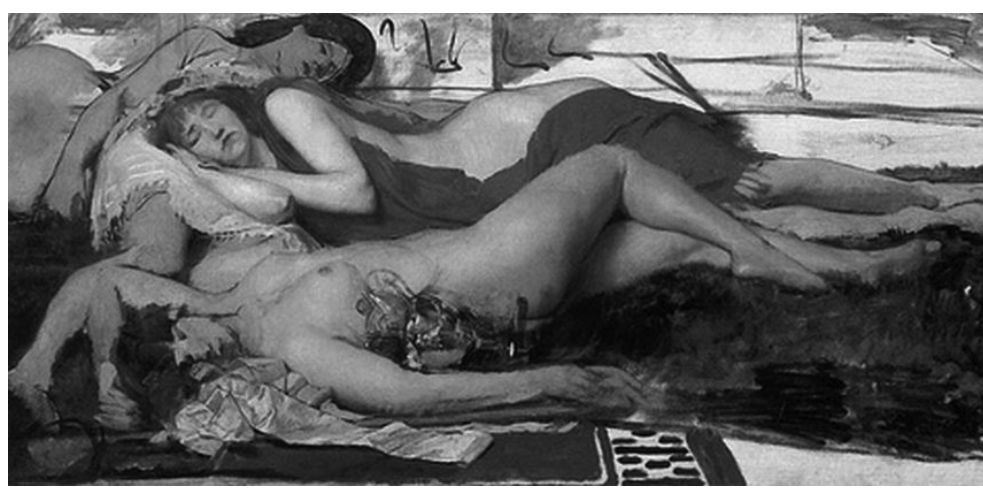

Fig.3. Exhausted Maenads after the Dance, 1874.

Sr. Lawrence Alma-Tadema. Ámsterdam, Museo Van Gogh. Óleo sobre lienzo. que a imitación de éstas, participan en los ritos ${ }^{40}$ orgiásticos en las Bacanales en honor a Dioniso, también llamado Baco (del epíteto griego Bók $\chi 10 \varsigma-\alpha-o v)^{41}$. Estas mujeres adquieren, por esta conexión con la divinidad y su consecuente enajenación, una fuerza sobrehumana y poderes adivinatorios, además se las ve en ocasiones dominando a las fieras y cabalgando en panteras o lobeznos. Dado que el cuento de Cortázar se limita a tomar simplemente la experiencia báquica como inspiración y no relata ninguno de los mitos en los que aparece ${ }^{42}$, no me detendré en narrarlos ${ }^{43}$. Sin embargo, hay que destacar las Bacantes de Eurípides ${ }^{44}$, representada en el 406 a.C $\mathrm{C}^{45}$, como texto

${ }^{37}$ «Mientras en los textos más antiguos aparece la palabra ménade (Véase Hom. Il. 23, 460-461 y h.Cer. 386), en época helenística y romana los autores hacen alusión a la representación pintada o esculpida con el término bacante, que emplea Eurípides en su obra Las Bacantes». Villanueva Puig (2009:22).

${ }^{38}$ «Ser poseído por un ardor furioso, de rabia. Dicho del guerrero, de hombres ebrios o llevados fuera de sí por la divinidad, dicho a veces del fuego etc. En activa embravecer o enfurecer es raro y secundario.

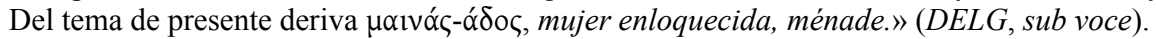

${ }^{39}$ Grimal (1994:348).

40 «En los tres cuentos se manifiesta la impresión que la plasticidad de los ritos orientales en el caso de "Circe"; dionisíaco, en el caso de "Ménades" y egeo, en "El ídolo de las Cícladas" produjo en Cortázar.» González de Tobía (2010:1011). En este sentido le interesa a Cortázar reflejar lo ritual, tal vez con cierta influencia historicista (Graves) de estos rituales en honor a Dioniso. Sin embargo, la manera de presentarlos como verosímiles y sin estar bajo los efectos de la ingesta de sustancias de cualquier tipo, hace que la interpretación se acerque más al psicologismo, que venimos defendiendo.

${ }^{41}$ Grimal (1994: 348). Fue Rapp quien distinguió, a partir de los testimonios escritos e iconográficos, las ménades históricas de las míticas. (1872: 1-22).

${ }^{42}$ No hay que olvidar lo que simboliza Dioniso para Jung «Dioniso significa el abismo sin fondo de la apasionada disolución de toda particularidad humana en la divinidad animalizada del alma inicial» (1989: 67). Es decir, Jung relaciona a Dioniso con una disolución del individuo que puede llevar sus emociones hasta el paroxismo.

${ }^{43}$ Para una relación completa de los mitos referentes a Dioniso véase Ruiz de Elvira (2011:175-185).

${ }^{44}$ Para una visión de la representación en la obra de Eurípides de Dioniso y los ritos surgidos en torno a su culto véase: Winnington-Ingram (1969: 49-59).

${ }^{45}$ López Férez (2008: 352-395). 
fundamental para el conocimiento de estas divinidades; aunque aparecen en menor medida en otras obras literarias ${ }^{46}$. Parece ser Eurípides quien ha influido a Cortázar ${ }^{47}$, sin olvidar la tradición cultural reflejada en las artes figurativas ${ }^{48}$.

Tras este bosquejo de las fuentes clásicas quiero adentrarme en el puro análisis mitológico del relato de Cortázar. En primer lugar quisiera comentar ciertos aspectos técnicos que sirven a Cortázar para emular los procesos de enajenación de la mente, que parecerían padecer estas mujeres de la antigüedad, e incluso traérnoslas hasta la contemporaneidad de forma verosímil. Cortázar remite a los propios ritos griegos, donde la danza, la música y una primaria instrumentación, regían gran parte de los rituales en honor a la divinidad. Incluso en la iconografía vemos a estas mujeres bailando al son de címbalo y aulós ${ }^{49}$. Es por ello por lo que el elemento en torno al cual se organiza el relato es la música.

La estructura del relato se ordena siguiendo el programa musical que se ofrece en el Teatro de Corona ${ }^{50}$. Ésta encaja perfectamente con una gradación ascendente en cuanto a la fuerza de las piezas musicales y, a su vez, con el proceso de enajenación padecido por las bacantes. Cortázar sugiere que, incluso en un concierto de nuestra realidad, cualquier ser humano puede ser captado por un delirio en el que su pasión lo lleve hasta alcanzar la irracionalidad suma. Sigue a esta enajenación un anticlímax, una gran calma y recuperación de las capacidades mentales básicas. Es decir, como ya he expresado, se muestra que este estado de ebriedad produce una pérdida de las percepciones sensoriales, adquiriendo otras por contrapartida.

Es importante señalar también la función que tiene en el relato un narrador en primera persona que parece estar en todo momento ajeno al rito musical, refiere en varias ocasiones que no le gusta el programa: «Sólo yo de puro aburrido podía meterme en un concierto donde después de Strauss, Debussy, y sobre el pucho Beethoven contra todos los mandatos humanos y divinos ${ }^{51} »$ (pág. 51). «-No me incluya, por

${ }^{46}$ Para algunas de estas referencias véase: S., Ant .1150; OV., Met. 4 ,1-30 y Fast. 4, 458, y 6, 504; SIL.3, 102 y PERS. 1, 105.

${ }^{47}$ En el catálogo de la Biblioteca de Julio Cortázar consta: Ten plays / by Euripides; translated by Moses Hadas and John McLean; with an introduction by Moses Hadas. Editorial: New York: Bantam Books, 1960. (Véase: http://www.march.es/bibliotecas/repositorio-cortazar/ficha.aspx?l=1\&p0=cortazar:656). Aunque la edición es posterior a la redacción del cuento, e incluso sabemos que la adquirió en 1962 por la nota manuscrita del propio Cortázar en el volumen, su existencia en la biblioteca del autor nos muestra el interés por la obra, que sería muy anterior, seguramente cercano a la etapa en la que estudió con detenimiento la mitología, como hemos explicado supra.

${ }^{48}$ M.C. Villanueva Puig parte en su estudio sobre las Ménades de tres fuentes de documentación: los textos literarios (Destacando E., $B a$.), documentación histórica y las representaciones en las artes decorativas. De esta última fuente de información señala la autora: «La representación de ménades en las artes figurativas ocupan un período muy largo. Son ellas las que permiten remontarse a una época muy antigua, sobre el v siglo de Atenas, y observar la fortuna del tema hasta el fin de la antigüedad.(...) La tragedia dionisíaca de Eurípides se sitúa un siglo y medio después de las imágenes más antiguas del personaje que le da su nombre. Sin embargo, ésta constituye el testimonio escrito conservado más próximo cronológica y geográficamente a ellas». Villanueva Puig (1969: 23-24).

${ }^{49}$ Para repertorio completo de estas imágenes puede consultarse Krauskopf (1997: 548-555).

${ }^{50}$ Para un estudio completo sobre la música en este cuento véase Planells (1980: 609-614).

${ }^{51}$ Cito todos los ejemplos del cuento de Cortázar «Ménades» a partir de Cortázar (2003:50-66). 
favor - dije- En materia de música tengo una confusión mental. Este programa, por ejemplo, me parece horrendo. Pero sin duda me equivoco» (pág. 53). El personajenarrador muestra su lejanía y su disconformidad en este rito, que será conducido por el Maestro, director de orquesta, como si del propio Baco se tratara. Creo imprescindible trazar primeramente la estructura que señalo, para luego pasar a analizar en qué consiste este furor báquico que paulatinamente se adueñará del relato y de todos sus constituyentes.

Podríamos decir que el relato se divide en seis fases, seis estados de la psique humana, que van de la calma al furor y de éste a la nueva calma:

1. Calma inicial, predominio de lo apolíneo en la descripción del inicio sobre el «perfecto equilibrio acústico».

2. El sueño de una noche de verano de Mendelssohn. La primera pieza «los pondría cómodos», nos dice el narrador.

3. Don Juan de Strauss. Es calificada como «generosa» y «redonda». Les haría «sentirse artistas».

\section{/INTERVALO EN EL FOYER Y EN EL BAR/}

4. El mar de Debussy. Hasta el protagonista se deja atrapar por «los vaivenes sonoros» y nos dice: «aplaudí hasta que me dolieron las manos». La mujer de rojo aparece. Gran ovación.

/Dos MinUtos DE DESCANSO IMPROVISADOS POR EL MAESTRO/

5. La Quinta Sinfonía de Beethoven. «El gran masaje vibratorio». «El éxtasis de la tragedia». Gritos, convulsiones: «furor báquico».

6. Cese de la música y del furor: la nueva calma. Anticlímax.

Como ya se ha dicho, el relato se abre con la descripción de la toma de asiento del oyente en la fila nueve del Teatro Corona, examinando cómo alcanzar «el perfecto equilibrio acústico»:

Fila nueve, ligeramente hacia la derecha: el perfecto equilibrio acústico. Conozco bien el teatro Corona y sé que tiene caprichos de mujer histérica. A mis amigos les aconsejo que no acepten jamás fila trece, porque hay una especie de pozo de aire donde no entra la música; ni tampoco el lado izquierdo de las tertulias, porque al igual que en el Teatro Comunale de Florencia, algunos instrumentos dan la impresión de apartarse de la orquesta, flotar en el aire, y es asi como una flauta puede ponerse a sonar a tres metros de uno mientras el resto continúa correctamente en la escena, lo cual será pintoresco pero muy poco agradable (pág. 51, cursiva mía).

En esta descripción encontramos la calma, la precisión y el equilibrio predominantes en las notas musicales ${ }^{52}$. El Maestro parece ser el conductor perfecto para esta armonía que se mantiene durante la primera pieza. Sin embargo, para que esta captación

${ }^{52}$ Se ve claramente la oposición entre lo dionisíaco y lo apolíneo durante el cuento. Esta oposición está inspirada, sin duda alguna, en El nacimiento de la tragedia de Nietzsche. véase Goyalde, 1998: 39. Según explica muy acertadamente el propio Goyalde existe en el relato una gran variedad de oposiciones (crudo/cocido, salvaje/ civilizado, Dioniso /Apolo etc.), que sirven a Cortázar para cuestionar aque- 
mental surta efecto es preciso también que exista una predisposición. Como se puede observar claramente en el caso del narrador, éste se mantiene expectante, no deja que la música entre en él, como si sólo debiera tomar nota de esta extraña reacción psicológica: «Me dolía un poco no estar del todo en el juego, mirar a esa gente desde fuera, a lo entomólogo. Qué le iba a hacer, es una cosa que me ocurre siempre en la vida, y casi he llegado a aprovechar esta aptitud para no comprometerme en nada» (pág. 56).

Se oponen a su reacción todas las bacantes que parecen entrar en seguida en la música del Maestro al que no ponen en duda, pues lo consideran una especie de intermediario entre la música y el entusiasmo que ésta logra crear en sus almas. Desde el primer descanso podemos observar la impresión que el Maestro causa en todos, nadie permanece impertérrito ante su arte: la Señora de Jonatán, Guillermina Fontán, las chicas de Epifanía, Cayo, etc. Nadie parece inmune a la herida que la música abre en sus almas. Sin embargo, tras este descanso muchos de los devotos muestran aún actitud ordenada: «los melómanos provistos de partituras ensayaban sus métodos de iluminación» (pág. 59), que posteriormente parecen abandonar. Incluso podemos ir más allá, existe un personaje inmune al Maestro: un ciego que se sentaba «dos o tres plateas más allá» y en el que el narrador parece encontrar un punto de resistencia ante esta nueva divinidad, como si del propio Penteo se tratara. Es decir, comparándolo con la obra de Eurípides, además de identificar a este Maestro con la divinidad báquica, podemos ver en la actitud, en el carácter psicológico del protagonista del relato: un trasunto del propio Penteo, rey de Tebas e hijo de la bacante Ágave, el cual se opone al culto a Baco. A partir de la tercera pieza, el narrador parece dejarse seducir por la música («Yo mismo me dejé atrapar por el último movimiento, con sus fragores y sus inmensos vaivenes sonoros, y aplaudí hasta que me dolieron las manos» pág. 57) e incluso aplaude el ciego, que parecía tal vez dotado con la sabiduría que caracteriza a los ciegos. No podemos olvidar que el propio Tiresias, adivino ciego del ciclo Tebano, es personaje de Bacantes de Eurípides. A partir de este momento la agitación irá in crescendo. Ya no se trata de la música, sino del «Maestro y al sentimiento colectivo que envolvía la sala, la fuerza de la ovación empezaba a alimentarse a sí misma, crecía por momentos y se tornaba insoportable» (pág. 58). Llegados a este punto hace su entrada en escena la Ágave de esta historia contemporánea, a la que el rojo delata como suma sacerdotisa de este Maestro:

Vi a una mujer vestida de rojo que corría aplaudiendo por el centro de la platea, y que se detenía al pie del podio, prácticamente a los pies del Maestro. Al inclinarse para saludar otra vez, el Maestro se encontró con la señora de rojo a tan poca distancia que se enderezó sorprendido (pág. 58).

Tras el refrigerio obligado después de esta exaltación sudorosa, se abre la Quinta de Beethoven: «el éxtasis de la tragedia». A partir de este momento se constituirá la verdadera bacanal. Se suceden los aplausos, los gritos, las convulsiones, la euforia en general:

llos modelos que el hombre contemporáneo occidental ha heredado de la antigüedad clásica. Goyalde (1998:39). 
Un grito seco y breve como de espasmo amoroso o de histeria. Su cabeza se dobló hacia atrás, sobre esa especie de raro unicornio de bronce que tienen las plateas del Corona, y al mismo tiempo sus pies golpearon furiosamente el suelo mientras las personas a su lado la sujetaban por los brazos (pág. 59-60, cursiva mía).

La descripción que he señalado en cursiva se asemeja sobremanera a la de las Ménades báquicas de Bacantes de Eurípides:

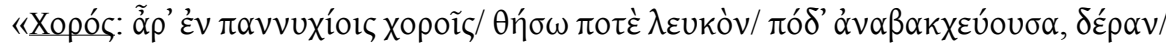

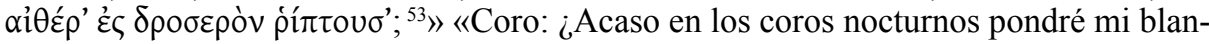
co pie, báquica danza, el cuello tendido al éter lleno de rocío?» (vv. 862-865, cursiva mía) $)^{54}$.

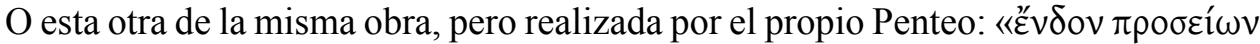

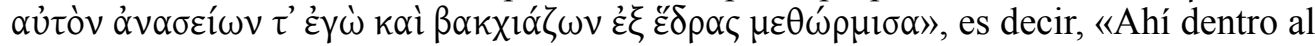
agitar hacia atrás y adelante mi cabeza y al danzar cual bacante lo saqué de su sitio» (vv. 930-931, cursiva mía).

Finalmente, la mujer de rojo avanza de forma hipnótica hacia el Maestro y se le une el resto del público, hasta el ciego pierde la compostura, se levanta el que era ejemplo de distanciamiento. Sin embargo, el gesto que me parece más significativo es la pérdida de la batuta por parte del Maestro, que parece que pierde el control del propio rito creado por él: el vino también tiene efecto de ebriedad en Dioniso, también a él lo aleja de sus facultades. El público se enfrenta de forma violenta, sumándose el propio protagonista. Parecen las bacantes creadas por Eurípides que en medio de la euforia no dudan en descuartizar a Penteo, creyendo que se trataba de un león. El Maestro está ya rodeado de la mujer de rojo y de sus seguidores, que se abalanzan sobre él, dándonos la impresión de que desaparece aplastado. La bacanal está siendo celebrada. Los gritos se amontonan en este evohé final:

Los gritos sobrepujaban ahora a los aplausos, la gente estaba demasiado ocupada abrazando y palmeando a los músicos para poder aplaudir, de modo que la calidad del estrépito iba virando a un tono cada vez más agudo, roto aquí y allá por verdaderos alaridos entre los que me pareció oír algunos con ese color especialísimo que da el sufrimiento, tanto que me pregunté si en las carreras y en los saltos no habría tipos quebrándose los brazos y las piernas, y a mi vez me tiré de vuelta a la platea ahora que el escenario estaba vacío y los músicos en posesión de sus admiradores que los llevaban en todas direcciones, parte hacia los palcos, donde confusamente se adivinaban movimientos y revuelos, parte hacia los estrechos pasillos que lateralmente conducen al foyer. Era de los palcos de donde venían los clamores más violentos como si los músicos, incapaces de resistir la presión y el ahogo de tantos brazos, pidieran desesperadamente que los dejaran respirar (pág. 64).

\footnotetext{
${ }^{53}$ Cito el texto griego de Bacantes a partir de la edición de Diggle, Oxford University Press, 1994.
}

${ }^{54}$ Cito los ejemplos en español de Rodríguez Adrados (2003: 161-252). 
En este momento el rojo de la mujer se materializa en la pura sangre de uno de los asistentes: «y andaba titubeando de un lado a otro con la cara cubierta de sangre» (pág. 65) ${ }^{55}$. Tras esta euforia que se llena de sangre, clamores y sobre todo confusión, que es en definitiva lo que mejor caracteriza un acto orgiástico o báquico, vuelve a triunfar la calma en la escena, al igual que en Bacantes Ágave con la cabeza en las manos de su hijo Penteo, al que había descuartizado, recupera el sentido y deja de creer

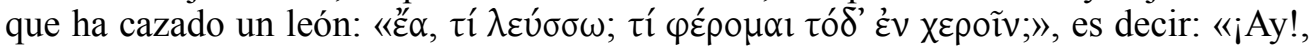
¿qué estoy viendo? ¿Qué es esto que transporto en mis manos?» (vv. 1280).

El final del relato de Cortázar nos muestra a esta ménade gozosa similar a Ágave, tras haber participado como sacerdotisa en este acto eufórico, en esta posesión, que ha permitido que toda la sala olvidase su condición humana, que trascendiera lo material y lo racional a través de lo orgiástico, de la furia del espíritu humano, que espera con la lengua en los labios otro momento de ebriedad. Vemos además una especie de transposición del mito, ya que en este caso es el dios la víctima del rito y no el espectador o el mirón, como veíamos en el descuartizamiento de Penteo. Tal vez con este «relamerse los labios», Cortázar quiera hacernos pensar que han devorado al Maestro, para poseer así aquello que los ha llevado hasta la catarsis en su interior: ahora la música formaría parte también de ellos.

Pero la mujer vestida de rojo iba al frente, mirando altaneramente, y cuando estuve a su lado vi que se pasaba la lengua por los labios, lenta y golosamente se pasaba la lengua por los labios que sonreían (pág. 66, cursiva mía).

\section{CONCLUSIONES}

A través del análisis de estos dos relatos de Cortázar, hemos podido comprobar que la mitología clásica ha seguido interesando aún a los autores del siglo xx, que han encontrado en ella una inagotable fuente de inspiración. En primer lugar, partiendo del análisis de la primera creación mitológica de Cortázar, Los reyes, hemos podido observar que ya en ella se atendía, sobre todo, a la psicología de los personajes míticos; aunque aún se presentaba una escenografía tradicional (Gabriel Vaccaro, 2007). Establecemos, además, que la visión de la mitología de Cortázar parte de la interpretación psicologista de Jung, como él mismo relata de forma anecdótica (A Fondo, 1997) y como vemos en el poema dramático Los reyes y en los dos relatos breves analizados.

En segundo lugar, a partir del análisis de la adaptación de la materia antigua llevada a cabo por Cortázar, hemos incluido los relatos de «Circe» y «Ménades» dentro de la

${ }^{55}$ La sangre tenía un papel importante, junto al vino, en los ritos relacionados con Dioniso: «Las mujeres son representadas frecuentemente en las pinturas de las vasijas derramando libaciones y haciendo varios tipos de ofrendas de sangre, pero ellas también aportan elementos importantes al proceso de sacrificio de sangre. El sacrificio de sangre tiene un inestimable valor en la cultura griega, como modo de permitir no sólo el conocimiento de la decisión de la divinidad, a través de la inspección de las entrañas de las víctimas, sino también la oportunidad de influir en la decisión a partir de la ofrenda de una víctima especialmente gratificante» Goff, (2004). «Una de las ceremonias es el despedazamiento de animales vivos, seguida de la ingestión de la carne cruda de los mismos (omofagia)» Ruiz de Elvira (2011: 179). 
tipología de obras que no toman el argumento del mito; sino que extraen sus personajes o su ambiente para sugerirlo y crear nuevas historias. No podemos olvidar que se trata de un procedimiento que ya utilizaron autores clásicos como Apuleyo (Cristóbal, 2000:32-33).

En tercer lugar, el relato «Circe» está directamente inspirado en la Odisea, que el mismo Cortázar afirma haber leído, y haber realizado un fichero mitológico con su contenido (Cortázar: 1985 ${ }^{\text {b}}: 30$ ). En nuestro estudio hemos expuesto sistemáticamente las similitudes que se dan entre ambas Circes. Hemos determinado algunas conexiones por primera vez y, en otros casos, hemos analizado con mayor profundidad aspectos que ya se habían citado en otros estudios previos. Nuestro análisis sistematiza los siguientes vínculos en los procesos de seducción de ambas mujeres:

1. Rasgos físicos: los cabellos aparecen descritos en ambos casos y la voz (Homero) o la música (Cortázar) les sirve para atraer a los hombres. En el caso de Delia también encontramos una descripción llamativa en la introducción de sus palabras en estilo directo.

2. La descripción como habilidosas amas de casa. Se insiste en dos tareas domésticas:

a) Los proyectos de costura y bordado de Delia pueden identificarse con la tarea de tejer de Circe.

b) Tanto Circe como Delia sirven a sus invitados comida y bebida, que ellas mismas preparan.

3. La brujería. Se identifican entre ellas diferentes poderes sobrenaturales:

a) Poder de dominación sobre los animales: Delia aparece como Пótvia $\theta \eta \rho \tilde{\omega} v$ al igual que Circe, infundiendo temor ante los animales que la rodean.

b) Poder adivinatorio: ambas parecen predecir el futuro. Circe narra a Odiseo sus futuras aventuras y Delia predice la muerte de un pez. En el caso de

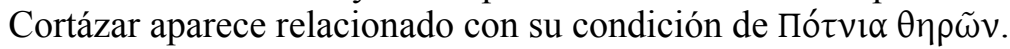

c) Elaboración de brebajes. Ambas preparan licores o pociones para dominar a sus víctimas, transformarlas o causarles la muerte. En el caso de Delia este elemento se refleja también en la elaboración de bombones, cuya descripción aparece rodeada de connotaciones mágicas y venenosas.

Respecto a la brujería hemos estudiado cómo Cortázar acomoda el elemento mítico-mágico a la cotidianidad para hacerlo verosímil. Se trata de un juego de doble enfoque, pues su realidad se vuelve mítica por la referencialidad, y el material mítico evocado se vuelve cotidiano para ajustarse a su creación. El que Cortázar no introduzca el elemento mágico de forma concreta permite una serie de juegos, llevados a cabo por el narrador, que hacen que el lector dude de la culpabilidad de Delia hasta el final del relato, e incluso entonces pueda interpretarlas como obsesiones creadas en la mente de los propios personajes. 
4. El erotismo: aparece como arma en ambas mujeres, aunque en el caso de Delia su sexualidad se realice de forma compleja y perversa, como si alcanzara la satisfacción sexual no de un contacto físico; sino de la propia posesión de sus víctimas, como vemos en la escena en la que Mario prueba el bombón.

De forma más breve hemos analizado la relación de estas mujeres con el resto de personajes que tienen contacto con ellas. Delia aparece, al igual que Circe, como ser aislado del resto del mundo. Por otro lado, Mario, sin la ayuda de un dios, se siente atrapado en esta seducción, hasta la catarsis del final del cuento.

En cuarto lugar, el relato de «Ménades» parece partir de Bacantes de Eurípides y la tradición literaria, filosófica e iconográfica que éste había brindado a nuestra cultura. Cortázar remite a estos rituales antiguos a partir de la música y la descripción de los movimientos de los participantes, que nos recuerdan a los de las mujeres descritas en Eurípides. Jung relacionaba a Dioniso con el símbolo de la disolución de la personalidad humana hasta el paroxismo. Este aspecto queda marcado, como hemos establecido, en la estructura de composición del propio texto, pues se organiza según el propio proceso de enajenación, en seis fases que van de la calma al éxtasis, para regresar a la calma.

En último lugar, además de la simbología del mito y su relación con la esencia del relato, hemos descrito algunos personajes que encuentran su paralelo en Bacantes de Eurípides:

1. EI Maestro nos recuerda a Dioniso, va a llevar hasta el extremo a un público que parece aletargado por una rutina que le oprime, aun cuando se dispone a la catarsis. Además observamos su similitud, al convertirse en víctima de este rito, con el propio Penteo descuartizado.

2. El narrador aparece como fuerza opuesta al rito, al igual que se oponía Penteo en Bacantes.

3. El ciego entre el público parece remitir a Tiresias de Bacantes.

4. La mujer vestida de rojo, a modo de suma sacerdotisa, nos recuerda a Ágave.

He querido así, con este pequeño análisis, reparar en estas personalidades psicológicas que han sido despertadas por Cortázar de la antigüedad clásica, muchas veces olvidadas, y mostrar el interés y la importancia que aún en el siglo xx, e incluso en el XXI, siguen teniendo. La mitología en la obra del autor argentino constituye la reelaboración del mito que, para el modelo de Levi-Strauss, formaría parte del mismo arquetipo que las interpretaciones clásicas. La mitología, que parece desprestigiada como si de cuentos sin importancia se tratara, muestra haber bebido de la propia experiencia humana y representarla de forma simbólica, para plasmar la psicología, verdadera fuente de la creación artística. 


\section{BIBLIOGRAFÍA}

Aguirre Castro, Mercedes (1994), «El tema de la mujer fatal en la Odisea», $C F C(G)$ Vol 4: 301-317.

AlazRAKI, Jaime (1994), Hacia Cortázar: aproximaciones a su obra, Barcelona: Anthropos. Álvarez, Consuelo \& Iglesias, Rosa $\mathrm{M}^{\mathrm{a}}\left(2007^{8}\right)$, Ovidio Metamorfosis (Traducción y edición), Madrid: Cátedra.

CAmpra, Rosalba (2009), Cortázar para cómplices, Madrid: del Centro Editores.

Carroll, Lewis (1997), A través del espejo y lo que Alicia encontró al otro lado, Madrid: Alianza Editorial.

Cortázar, Julio (1946), Jean Giono. El nacimiento de la «Odisea» (Traducción), Argentina: Argos.

- $\left(1985^{\mathrm{a}}\right)$, Los reyes, Madrid: Alfaguara.

- $\left(1985^{\mathrm{b}}\right)$, Salvo el Crepúsculo, Madrid: Alfaguara.

- $\left(2003^{\mathrm{a}}\right)$, Bestiario, Buenos Aires: Alfaguara.

- $\left(2003^{\mathrm{b}}\right)$, Final del juego, Buenos Aires: Alfaguara.

- $\left(2010^{20}\right)$, Las armas secretas (Edición de S. Jakfalvi), Madrid: Cátedra.

- $\left(2010^{21}\right)$, Rayuela (Edición de Andrés Amorós), Madrid: Cátedra.

CRANE, Gregory (1988), Calypso: Backgrounds and the Conventions of the «Odyssey», Frankfurt am Main: Athenäum.

CRistóbal LóPez, Vicente (2000), «Mitología clásica en la literatura española: consideraciones generales y bibliografía», $C F C(L)$. 18: 29-76.

De Mora VAlCÁRCel, Carmen (1982), Teoría y práctica del cuento en los relatos de Cortázar, Sevilla: Universidad de Sevilla.

De Paco Serrano, Diana M \& VÁsquez Rodríguez, Gilberto (2010), «Mitos clásicos en la obra de Mario Vargas Llosa», en J. A. López Férez (ed.), Mitos clásicos en la literatura española e hispanoamericana del siglo XX, t. II, Madrid: Ediciones Clásicas: 897-916.

Dee, James H (2001), Epitheta Deorum apud Homerum. The Epithetic Phrases for the Homeric Gods, Hildesheim ; Zürich ; New York : Olms-Weidmann.

Del Río, Emilio (2010), «La mitología clásica en Borges», en J. A. López Férez (ed.), Mitos clásicos en la literatura española e hispanoamericana del siglo XX, t. II, Madrid: Ediciones Clásicas: 990-1002.

Dimeo Álvarez,Carlos (2012), «De lo “inter” a lo "trans”. Nuevas poéticas y fronteras de la teatralidad y la narración: (Estudio del texto Los reyes, de Julio Cortázar)», en R. Alemany Ferrer y F. Chico Rico (coord.), Literature i espectacle, Alicante: Universidad de Alicante: 163-172.

Esteban Santos, Alicia (2007), «Para salir del Laberinto: referencias mitológicas en un cuento del puertorriqueño René Marqués» en A. Bernabé, I. Rodríguez Alfageme (edd.), Phíloy skiá. Studia philologiae in honorem Rosae Aguilar, Madrid, Universidad Complutense: 253-264.

- (2010), Mujeres enamoradas: Mujeres terribles. La mujer, el monstruo, el laberinto... y el héroe (Introducción, comentarios y obras teatrales de Alicia Esteban), Madrid: Dhyana Arte.

Felson-Rubin, Nancy (1994), Regarding Penelope from character to poetics, USA: Princeton University Press. 
Gabriel Vaccaro, Santo (2007), «El mito del Minotauro en La casa de Asterión de Borges y en Los reyes de J. Cortázar», Espéculo: Revista de Estudios literarios, n. ${ }^{\circ}$ 34: html. http:// dialnet.unirioja.es/servlet/articulo? codigo $=3034542$

García Gual, Carlos (2007), Introducción a la mitología griega, Madrid: Alianza Editorial.

Goff, Barbara (2004), Citizen Bacchae, California: University of California Press.

GonzÁlez de Tobia, Ana María (2010), «Julio Cortázar y el mito griego. Vinculación y contraste con algunos tratamientos de Borges y Marechal», en J. A. López Férez (ed.), Mitos clásicos en la literatura española e hispanoamericana del siglo XX, t. II, Madrid: Ediciones Clásicas: 1003-1019.

Goyalde Palacios, Patricio (1998), «Circe de Julio Cortázar: una lectura intertextual», Arrabal 1: 113-118.

- $(2001)^{\mathrm{a}}$ «Las Ménades de Julio Cortázar : mito clásico y recreación literaria», Faventia 32/2: $35-42$.

- $(2001)^{\mathrm{b}}$, La interpretación, el texto y sus fronteras. Estudio de las interpretaciones críticas de los cuentos de Julio Cortázar. Madrid: UNED ediciones.

Graves, Rovert (2004 ${ }^{11}$ ), Los mitos griegos, Madrid: Alianza Editorial.

Grimal, Pierre, Diccionario de mitología griega y romana, Barcelona: Paidós.

Gualerzi, Saverio (2007), Penelope o della tessitura. Trame femminili da Omero a Ovidio, Bari: Palomar.

Henderson, Joseph.L. (1995), «Los mitos antiguos y el hombre moderno», en C. G. Jung (ed.), El hombre y sus símbolos, Barcelona: Paidós Ibérica.

Houvenaghel, Eugenia \& Monballieu, Aagje, «El retorno de la mujer fatal en "Circe” de Julio Cortázar», Bulletin of Hispanic studies. Vol 85, n. ${ }^{\circ}$ 6: 853-866.

Huici, Adrián (1998), El mito clásico en la obra de Jorge Luis Borges. El laberinto, Sevilla: Alfar: 121-259.

Huidobro, Vicente $\left(2011^{17}\right)$, Altazor. Temblor del cielo, Madrid: Cátedra.

Jung, Carl G. (1989), Psicología y alquimia, Barcelona: Plaza \& Janés.

KRAUSKOPF, Ingrid \& SimON, Erica (1997), s. v. «Mainades», LIMC VIII 2, Zürich; Düsseldorf: Artemis: 548-555.

Lévi-Strauss, Claude \& Propp, Vladimir (1982), Polémica, Madrid: Fundamentos.

LÉVI-STrauss, Claude (1995), Antropología estructural, Barcelona: Paidós.

LiÑARES, Lucía A. (1999), «La voz del personaje y el discurso de Circe de Cortázar», en M. C. Álvarez Morán \& R. M. Iglesias Montiel (ed.), Contemporaneidad de los clásicos en el umbral del tercer milenio: actas del congreso internacional de los clásicos. La tradición grecolatina ante el siglo XXI (La Habana, 1 a 5 de diciembre de 1998), Murcia: Universidad de Murcia: 105-114. Disponible en: http://interclassica.um.es/investigacion/actas_homenajes/contemporaneidad_de_los_clasicos_en_el_umbral_del_tercer_milenio/1/la_voz_del_ personaje_y_el_discurso_epico_circe_de_cortazar

López FÉrez, Juan Antonio (2008), Historia de la literatura Griega, Madrid: Gredos.

Louden, Bruce Homer 's Odyssey and the Near East, Cambridge: Cambridge University Press.

Oviedo Pérez de Tudela, Rocío (1996), «El impacto de la imagen: el cuento de Cortázar entre surrealismo y fantasía», en V. Polo García (ed.), Conversaciones de famas y cronopios. Encuentros con Julio Cortázar. Murcia: Campobell.

PABón, José M. ${ }^{\mathrm{a}}$, (2005), Homero. «Odisea». (Traducción de José Manuel Pabón e introducción de Manuel Fernández Galiano) Madrid: Gredos. 
Picon Garfield, Evelyn (1975), ¿Es Julio Cortázar un surrealista?, Madrid: Gredos.

Planells, Antonio (1980), «Narración y música en Las Ménades de Julio Cortázar», Cuadernos hispanoamericanos, $\mathrm{n}^{\circ}{ }^{\circ}$ 664-366: 609-614.

Prope, Vladimir (2008), Las raíces históricas del cuento, Madrid: Fundamentos colección Arte.

-(2009), Morfología del cuento, Madrid:Akal.

RAPP, A (1872) «Die Mänade im griechischen Cultus, in der Kunst und Poesie», RHM 27, 1-22.

Rodríguez Adrados, Francisco (2003), «Andrómaca». «Heracles Loco». «Las Bacantes». Eurípides. (Edición, traducción y notas), Madrid: Alianza Editorial.

Ruiz de ElvirA, Antonio (2011), Mitología Clásica, Madrid: Gredos.

SHAw, Donal Leslie (1989), «A propósito de La casa de Asterión de Borges», en S. Neumeister (ed.), Actas del IX Congreso de la Asociación Internacional de Hispanistas: 18-23 agosto 1986, Vol 2, Berlín: 721-724.

Villanueva Puig, Marie-Christine (2009), Ménades Recherches sur la genèse iconographique $d u$ thiase féminin de Dionysos des origines à la fin de la période archaïque, Paris: Les Belles Lettres.

Winnington-Ingram, Reginald Pepys (1969), Euripides and Dionysus. An Interpretation of the Bacchae, Amsterdam. 